\title{
Geochronology and mantle source characteristics of kimberlites and related rocks from the Rae Craton, Melville Peninsula, Nunavut, Canada
}

\author{
Chiranjeeb Sarkar $^{1 *}$, Bruce A. Kjarsgaard ${ }^{2}$, D. Graham Pearson ${ }^{1}$, Larry M. Heaman ${ }^{1}$, \\ John P. Armstrong ${ }^{3}$ \\ ${ }^{1}$ Department of Earth and Atmospheric Sciences, University of Alberta, 1-26 Earth Sciences Building, \\ Edmonton, Alberta, Canada T6G $2 E 3$ \\ ${ }^{2}$ Geological Survey of Canada, 601 Booth Street, Ottawa, Ontario, Canada, K1A OE8 \\ ${ }^{3}$ Lucara Diamond, Vancouver, Canada V6C 3E8
}

\section{Introduction}

Kimberlites of the Qilalugaq cluster were first discovered in 2003 by BHP Billiton approximately 10 $\mathrm{km}$ NE of the hamlet of Repulse Bay on the Rae Isthmus, southern Melville Peninsula, Nunavut, NE Canada. The Aviat kimberlite cluster was discovered by Stornoway Diamonds in 2002, approximately $60 \mathrm{~km}$ WSW of Igloolik on the Melville Peninsula (Fig 1). Subsequent detailed exploration program on these kimberlites reavealed that kimberlites in both of these clusters are diamondiferous. The grade of Aviat kimberlites (80-160 carat per hundred ton) is significantly higher than those of the Qilalugaq cluster (14-40 carat per hundred ton). In this study, we present the first U-Pb perovskite $\left(\mathrm{CaTiO}_{3}\right)$ geochronology of several kimberlite bodies to determine their emplacement ages along with the tracer isotope data to evaluate the evolution and nature of the mantle sources. We have also carried out new mineralogical and petrograpic characterisation of these kimberlites to comment on their nomenclature and degree of alteration.

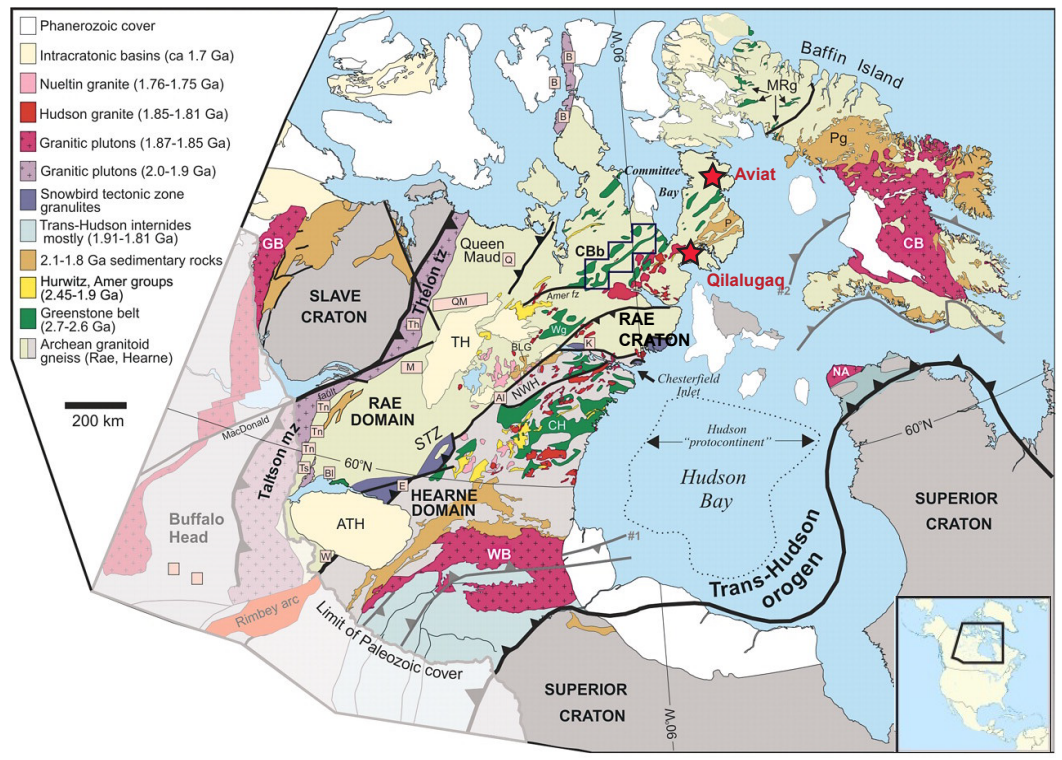

Fig 1: Simplified geological map of the Canadian Shield (modified after Berman, et al. (2005)). Location of Aviat and Qilalugaq kimberlite clusters shown by red stars.

\section{Kimberlites and sampling}

Both the Aviat and Qilalugaq kimberlite clusters intruded Archean tonalite-granodiorite gneisses, metasedimentary and metavolcanic rocks of the Rae craton (Dredge 2002). The Aviat cluster comprises 3 kimberlite pipes (AV1, AV4 and AV9) and five sheet-like bodies (AV2, AV3, AV5, AV8 and AV267; (Armstrong, et al. 2008)). All Aviat kimberlites occur within a $10 \mathrm{~km}$ long and 3 
$\mathrm{km}$ wide corridor. The Aviat pipes mostly consist of coherent (hypabyssal) kimberlite (HK) to tuffisitic kimberlite breccia (TKB) while the sheet-like structures are dominated by HK and hypabyssal kimberlite breccia (HKB). The Qilalugaq cluster, located $\sim 300 \mathrm{~km}$ to the south of Aviat, also consists of numerous kimberlite bodies including the Q1-4 complex that comprises four coalescing phases (A28, A48, A61 and A88) and several isolated kimberlite pipes (A34, A42, A59, A76, A94, A95, A152). Several dyke-like structures (Naujaat 1 to Naujaat 8) of varaible width (1.5 m to $4.5 \mathrm{~m}$ ) were also discovered (Kupsch and Armstrong 2013). The dominant phase in most of the Qilalugaq pipes and the dykes is a massive volcanoclastic kimberlite (MVK) that can be classified as $\mathrm{TKB}$, which commonly transitions toward HK with depth. They all show variable degrees of country rock dilution with the dykes being diluted more than the pipes. Qilalugaq kimberlites contain peridotitic xenoliths with mutli-modal Re-depletion ages ranging from Archean (3.0-2.7 Ga), Paleoproterozoic $(2.1-1.7 \mathrm{Ga})$ and "Recent" $(<1 \mathrm{Ga})$, suggesting the kimberlites intruded through a complex layered lithosphere (Liu, et al. 2016).

Samples were collceted from both kimberlite clusters in the summer of 2012, from the pits and trenches remaining after the earlier exploration. Some drill core samples were also used for petrographic and mineralogical study. Relatively hard and unaltered HK were chosen for perovskite recovery following a standard heavy mineral separation.

\section{Petrography and Mineralogy}

The Aviat pipes and sheets examined are all hypabyssal (coherent) rocks and are broadly similar from a mineralogical perspective. Large olivine grains are set in a groundmass of olivine, apatite, perovskite, spinel (chromite zoned to Ti-magnetite), ilmenite, calcite and poikilitic, zoned phlogopite. All olivine grains are variably replaced by calcite and/or serpentine. However, the Aviat sheets are distinctive in that apatite, perovskite and calcite are less abundant, and there is a higher proportion of groundmass ilmenite and spinel as compared to samples from the Aviat pipes. In the sheets, rutile +/dolomite is also observed as secondary mineral(s). The Quilalugaq and Naujaat samples are quite variably altered; the Naujaat dykes being extensively carbonatized ( $>60 \%$ dolomite, $+/$-calcite), or silicified (45-60 $\mathrm{wt} \% \mathrm{SiO}_{2}$ ). In the Naujaat samples, the olivine is completely replaced; only groundmass apatite, spinel and phlogopite are preserved, with secondary rutile and dolomite. Hypabyssal (coherent) samples from A34, A88 and A94 are similar, with olivine (replaced by serpentine and/or carbonate) set in a groundmass of apatite, spinel (chromite zoned to Ti-magnetite), phlogopite, calcite (+/-dolomite), +/-perovskite. All of the samples noted above from Aviat, Quilalugaq and Naujaat classify as being kimberlite, using the criteria of Woolley, et al. (1996). However, hypabyssal samples from Quilalugaq A61 consist of olivine set in a groundmass of apatite, perovskite, spinel, tetraferriphlogopite, calcite, augite and Ti-andradite (schorlomite-melanite) garnet; the latter two minerals consistent with these samples being ultramafic lamprophyres or orangeites, but not Gp I (archetypal) kimberlites. Mineral chemistry studies are currently being undertaken to refine the classification of these rocks.

\section{Results and Discussion}

ID-TIMS U-Pb analyses of seven perovskite fractions from both Aviat and Qilalugaq kimberlites indicate their early Cambrian age. While the major pipes from both clusters were emplaced between 531 and $536 \mathrm{Ma}$, the sheet-like kimberlite bodies at Aviat are $30 \mathrm{Ma}$ younger, emplaced between 503 and $507 \mathrm{Ma}$. Perovskite U-Pb results from the Naujaat dykes, gave a Proterozoic date, but is considered unreliable due to their unusually high common $\mathrm{Pb}$ correction. In general, Cambrian kimberlites are uncommon worldwide. The $\sim 530$ Ma Venetia kimberlite in South Africa is perhaps the best known. However, there are several kimberlite clusters of Late Neoproterozoic to Eocambrian age that have been reported from North America and some of these have economic diamond potential. These include Pelly Bay from Rae craton (Kienlen, et al. 2008; Liu, et al. 2016), Snap Lake and Gahcho Kué from SE Slave craton (Heaman, et al. 2004), Renard and Wemindji from the Superior craton (Tappe, et al. 2016), Chicken Park and George Creek from the Wyoming craton (Heaman, et al. 2004). Several other kimberlites (Labrador Sea Province, Lac Beaver kimberlite) and related rocks 
(ultramafic lamprophyres and carbonatites from Labrador and west Greenland) of similar age have been reported from eastern North America and western Greenland (Heaman, et al. 2004; Tappe, et al. 2014). This region of north-eastern North America and western Greenland has been termed the Eocambrian/Cambrian Labrador Sea Province and the magmatism here has been suggested to be associated to Eocambrian rifting along the northeastern margin of Laurentia and opening of the Iapetus Ocean (Heaman, et al. 2004).

$\mathrm{Sr}-\mathrm{Nd}$ tracer isotopes were also obtained on the same perovskite fractions used for $\mathrm{U}-\mathrm{Pb}$ dating from Qilalugaq and Aviat. The main kimberlite pipes at Qilalugaq (A61 and A94) and Aviat (AV1) have overlapping, relatively restricted ${ }^{87} \mathrm{Sr} /{ }^{86} \mathrm{Sr}_{\mathrm{i}}$, varying between 0.70405 and 0.70465 . The $\mathrm{Sr}$ isotopic signature of these pipes are slightly more radiogenic than typical Cretaceous age Group I kimberlites from South Africa (Nowell, et al. 2004) but are very similar to other Canadian kimberlites, such as Lac de Gras, Kirkland Lake, Somerset Island, and Fort à la Corne (e.g., Tappe, et al. (2013)). In contrast, the sheet-like bodies (AV2 and AV6) have considerably more radiogenic signatures $\left({ }^{87} \mathrm{Sr} /{ }^{86} \mathrm{Sr}_{\mathrm{i}}=0.70948-0.70969\right)$. Initial $\varepsilon \mathrm{Nd}$ values from Qilalugaq kimberlites define a very narrow range of +4.2 and +4.7 , consistent with the restricted ${ }^{87} \mathrm{Sr}^{86} \mathrm{Sr}_{i}$ values. In contrast, those from Aviat kimberlites cluster around chondritic values $(-1.5$ to +1.5$)$. The homogeneous $\mathrm{Sr}-\mathrm{Nd}$ isotopic nature of the main kimberlites from Aviat and Qilalugaq and their position on a mantle array in $\varepsilon \mathrm{Nd} \mathrm{vs}{ }^{87} \mathrm{Sr} /{ }^{86} \mathrm{Sr}$ space suggest their derivation from the asthenosphere or transition zone. However, the more radiogenic signature recorded by the perovskites from sheet-like intrusions at Aviat are unlikely to be due to any contamination/alteration, as perovskite is much more robust to the effects of crustal contamination. Hence, these younger kimberlites may be derived from a Subcontinental Lithospheric Mantle source, similar to that recorded in high-T peridotite xenoliths entrained in the nearby Somerset Island kimberlites (Schmidberger and Francis 2001).

\section{References}

Armstrong J, Stubley M, Chang F (2008) Geology and exploration history of the Aviat kimberlite cluster, northern Rae craton, Melville Peninsula, Nunavut, Canada. In: 9th international kimberlite conference, Frankfurt, Germany, Extended Abstract, vol 266.

Berman RG, Sanborn-Barrie M, Stern RA, Carson CJ (2005) Tectonometamorphism at ca. 2.35 and 1.85 Ga in the Rae domain, western Churchill Province, Nunavut, Canada: insights from structural, metamorphic and in situ geochronological analysis of the southwestern Committee Bay Belt. The Canadian Mineralogist 43(1):409-442

Dredge LA (2002) Quaternary geology of southern Melville Peninsula, Nunavut: surface deposits, glacial history, environmental geology, and till geochemistry. Geological Survey of Canada,

Heaman LM, Kjarsgaard BA, Creaser RA (2004) The temporal evolution of North American kimberlites. Lithos 76(1):377397

Kienlen B, Blackmore E, Curry N, Gill G, Kolebaba M, Lyon R, Ozyer C, Pratt Z, Vanderspiegel R (2008) The Amaruk project in Canada's new Pelly Bay diamond district. In: 9th International Kimberlite Conference Extended Abstract, vol., p 00334

Kupsch B, Armstrong J (2013) Exploration and Geology of the Qilalugaq Kimberlites, Rae Isthmus, Nunavut, Canada. In: Proceedings of 10th International Kimberlite Conference, vol. Springer, pp 67-78

Liu J, Riches AJ, Pearson DG, Luo Y, Kienlen B, Kjarsgaard BA, Stachel T, Armstrong JP (2016) Age and evolution of the deep continental root beneath the central Rae craton, northern Canada. Precambrian Research 272:168-184

Nowell G, Pearson D, Bell D, Carlson R, Smith C, Kempton P, Noble S (2004) Hf isotope systematics of kimberlites and their megacrysts: new constraints on their source regions. Journal of Petrology 45(8):1583-1612

Schmidberger S, Francis D (2001) Constraints on the trace element composition of the Archean mantle root beneath Somerset Island, Arctic Canada. Journal of Petrology 42(6):1095-1117

Tappe S, Brand NB, Stracke A, van Acken D, Liu C-Z, Strauss H, Wu F-Y, Luguet A, Mitchell RH (2016) Plates or plumes in the origin of kimberlites: $\mathrm{U} / \mathrm{Pb}$ perovskite and $\mathrm{Sr}-\mathrm{Nd}-\mathrm{Hf}-\mathrm{Os}-\mathrm{CO}$ isotope constraints from the Superior craton (Canada). Chemical Geology

Tappe S, Graham Pearson D, Kjarsgaard BA, Nowell G, Dowall D (2013) Mantle transition zone input to kimberlite magmatism near a subduction zone: Origin of anomalous Nd-Hf isotope systematics at Lac de Gras, Canada. Earth and Planetary Science Letters 371-372(0):235-251

Tappe S, Kjarsgaard BA, Kurszlaukis S, Nowell GM, Phillips D (2014) Petrology and Nd-Hf isotope geochemistry of the Neoproterozoic Amon kimberlite sills, Baffin Island (Canada): evidence for deep mantle magmatic activity linked to supercontinent cycles. Journal of Petrology 55(10):2003-2042

Woolley AR, Bergman SC, Edgar AD, Le Bas MJ, Mitchell RH, Rock NM, Scott Smith B (1996) Classification of lamprophyres, lamproites, kimberlites, and the kalsilitic, melilitic, and leucitic rocks. Canadian Mineralogist 34:175186 